Article

\title{
Analysis of the Relationship between Ethanol Spot and Futures Prices in Brazil
}

\author{
Derick D. Quintino ${ }^{1}$, Sergio A. David ${ }^{2, *}$ and Carlos E. de F. Vian ${ }^{1}$ \\ 1 Department of Economics, Administration and Sociology, University of São Paulo, \\ 13418-900 Piracicaba, SP, Brazil; derickdq@usp.br (D.D.Q); cefvian@usp.br (C.E.d.F.V.) \\ 2 Department of Biosystems Engineering, University of São Paulo, 13635-900 Pirassununga, SP, Brazil \\ * Correspondence: sergiodavid@usp.br; Tel.: +55-19-3565-6711
}

Academic Editor: Nicholas Apergis

Received: 3 October 2016; Accepted: 15 March 2017; Published: 1 April 2017

\begin{abstract}
In this work, an investigation and analysis are carried out in order to observe the relationship between ethanol spot and futures prices in Brazil. We adopted the Engle and Granger co-integration approach. Also, we consider the information share method proposed by Hasbrouck in order to examine the market efficiency in price discovery and information transmission. Results show that although the futures market is efficient in price discovery and information transmission, the cash market leads the long-run price discovery process. This suggests that the underlying cause of the dominance of the available market over the futures market can be attributed to the market's relative concentration in wholesale ethanol distribution due to the formation of marketing pools by the ethanol mills, as well as the small number of distributors that control a significant portion of the market share.
\end{abstract}

Keywords: ethanol; futures markets; Brazil; price discovery; BM\&F-BOVESPA

JEL Classification: O13; D53

\section{Introduction}

The Institute of Sugar and Alcohol (IAA) was created in 1933 with the main objective of mitigating the strong international shock that affected the sugar market at the time. This allowed the safeguarding of production and prices of local agents (Szmrecsányi 1979; Ramos 1983). The sector's deregulation in the 1990s changed the entire institutional environment, including the pricing process of sugarcane-the basic raw material for sugar and ethanol production in Brazil-and freed the sugar and ethanol pricing mechanism, which has since then been determined by the market forces of supply and demand (Quintino and David 2013; De Moraes 2000).

With the gradual withdrawal of the state from the economy, the agents began to exert self-regulation to cope with the uncertainties inherent to the economic activity of the sugar-energy sector, particularly in price risk management (De Freitas Vian 2003). To face the new and turbulent scenario and offer a financial instrument that would meet the need to minimize price risks, the São Paulo stock exchange BM\&F-BOVESPA, or the Brazilian Securities, Commodities and Futures Exchange, launched futures contracts for sugar in 1995 and for ethanol in 2000, with a view to turning them into price references in the domestic market for ethanol, and internationally in the case of sugar (Burnquist et al. 2002).

The anhydrous and hydrous ethanol markets have different dynamics in Brazil. The productive structure is the same and the vast majority of plants produce both types of ethanol. The anhydrous spot market has price fixation influenced by the gasoline market that is extremely regulated by the Petrobrás (Brazilian Petroleum Company, Rio de Janeiro, Brazil) sales policies and the rules of 
percentage of ethanol addition in gasoline. In turn, the futures market for this product is influenced by the expectations of fuel distributors and Petrobrás.

Hydrous ethanol has a more dynamic spot market, as mills can sell directly to fuel distributors based on market conditions each month, with seasonality and regional market conditions.

The futures market for this product could reflect the expectations of the distributors, in case of enough liquidity.

With regard to the market structure, although the sector is still relatively fragmented, it is becoming increasingly consolidated with the entry of private and public domestic and foreign capital, driven by different business strategies such as the search for economies of scale and scope, and the vertical integration of activities. The ranking and presence of foreign capital in the sector has changed. This share increased from $7 \%$ in 2007 to $22 \%$ in early 2010, with the major groups including multinational trading companies such as Louis Dreyfus, Bunge and Tereos-Guarani. Also, it is important to note the increasing insertion of Petrobras in the ethanol chain through its acquisition of shares in Tereos and a partnership signed with the São Martinho group (Gordinho 2010).

These recent developments motivated us to investigate the dynamics and interrelationships between ethanol spot and futures prices ${ }^{1}$ in Brazil, and to ascertain if the current BM\&F-BOVESPA ethanol futures contract exerts its price discovery function. Price discovery in futures markets refers to the role of these markets in forming price expectations that will prevail in the available market. In the sphere of futures markets, low liquidity associated with information skewness can lead to market inefficiency, deficiency in the price discovery process, and reduced risk management capacity (Mattos and Garcia 2011).

The literature about Brazilian commodities futures markets is still little explored (Serra et al. 2011; Bentivoglio et al. 2016), notwithstanding the importance of agribusiness to the country's economy. A purpose of this study is to examine the relationship between ethanol spot and futures prices in Brazil. Thus, we aim not only to help the professionals associated with the sugar-energy industry gain a better understanding of the dynamics between spot and futures prices (Bekiros and Diks 2008) but also to contribute to the debate among specialists in the spheres of academia and government.

This present work analyzes the relationships between ethanol spot and future prices involving the most recent hydrous ethanol contract in Brazil. During this new period, a contract in local currency is established and deals with an alternative fuel to gasoline in the domestic market and its price formation takes place on the main fuel distribution center in the country (Paulínia). It is cash-settled and presents contractual innovations when compared to the previous contract (anhydrous ethanol), in dollars (Santos). In the latter case, a product aimed at exports that did not meet market expectations.

The results of this work are intended to complement the study published by Mattos and Garcia (2006) about the price discovery in the futures markets of Brazilian agricultural commodities with low liquidity. According to the authors, "the recent studies in price discovery tend to show that futures prices play a major role in the pricing process. However, when the focus turns to low-liquidity markets, the results are mixed". The results are mixed and it is necessary to understand some characteristics of specific commodities chains such as the volume traded, the market concentration, the volume exported and others important aspects in chain dynamics such as innovation and substitute products.

Therefore, having in mind the importance that the ethanol sector represents in the domestic and international market, we understand that it would be relevant to know in more depth the relations between ethanol spot and future prices. As previously mentioned, ethanol has specific characteristics: it is an important product in the Brazilian internal market; it presents a variable volume of exports and imports; and it has an important substitute, namely gasoline which is controlled by a government

1 Spot price is the current price of a given asset (e.g., currency, security, commodities, ... ) transitioned for immediate delivery, while future price refers to its expected value at a specific future date and place. 
company. For this reason, we chose to study ethanol in order to elucidate the importance of price discovery in this market.

This paper is structured as follows: after this introduction, Section 2 presents a literature review; Section 3 describes the methods and data used in the analysis; Section 4 discusses the results; and lastly, Section 5 offers our final remarks.

\section{Literature Review}

The literature on price discovery in futures markets is extensive. This section will focus on articles that have studied futures contracts in Brazil. In addition, papers that have studied commodities futures markets of low liquidity, such as ethanol futures contracts in Brazil between 2010 (year of contract re-launch) and 2012.

Figure 1 shows the monthly trading volume and open interest of ethanol in BM\&F-BOVESPA and Figure 2 presents the evolution of ethanol futures and spot prices in Brazil.

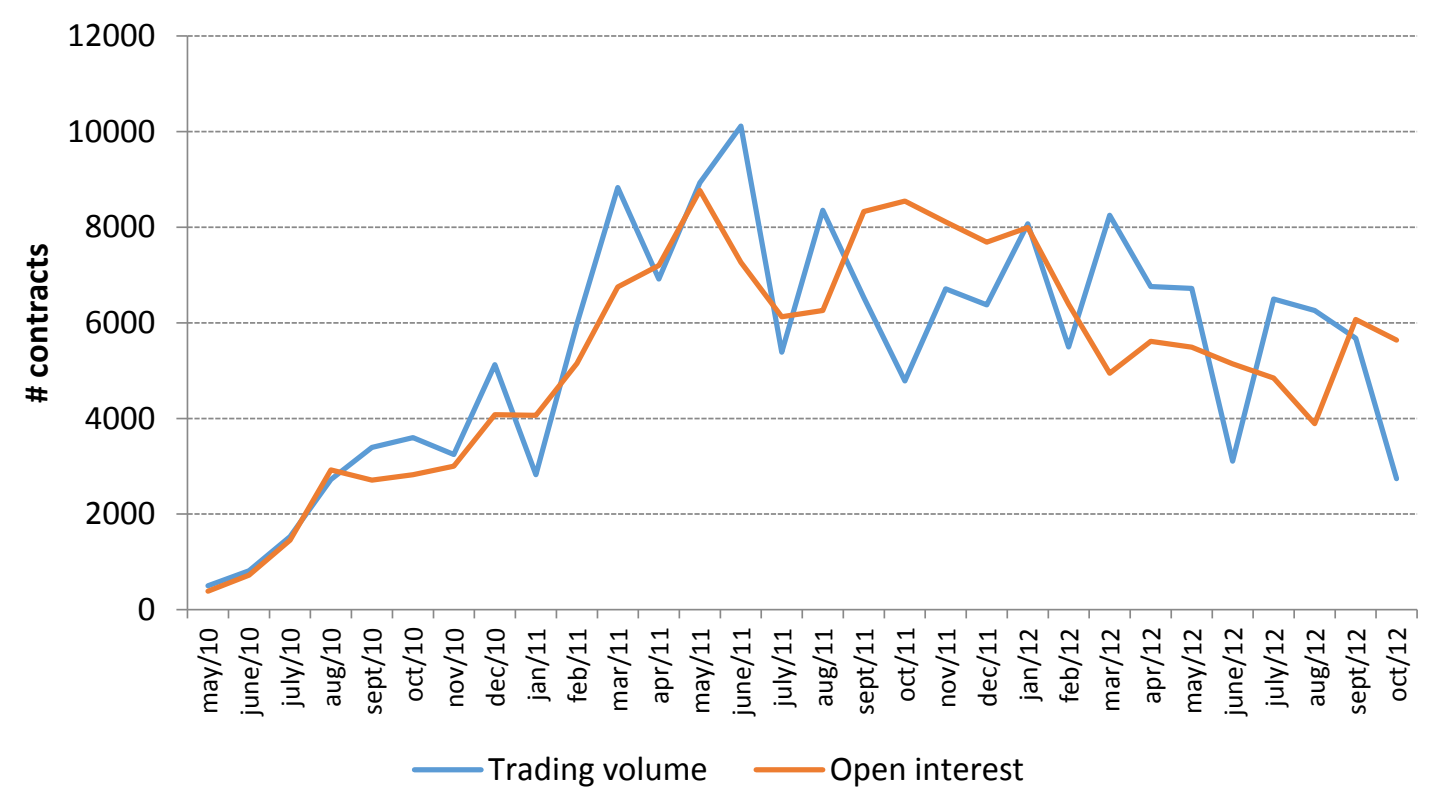

Figure 1. Monthly trading volume and open interest of ethanol in BM\&F-BOVESPA.

Mattos and Garcia (2004) studied price discovery in commodity futures markets in Brazil, using the Johansen and error correction methods to analyze the relationship between BM\&F-BOVESPA's spot and futures prices from 1995 to 2003. The authors found that, unlike high liquidity futures contracts such as beef and coffee, the sugar market of low liquidity played a more decisive role in long-term price discovery.

Perobelli (2005) analyzed the relationship between live cattle future and spot prices in the Brazilian market from October 2000 to March 2005, in the period when the meat packing plants entered the market, and therefore, all the links in the chain had agents operating in the futures markets. The econometric tool adopted was Engle and Granger's cointegration method (Alves et al. 2008; Granger and Newbold 1986). The author found that the two prices influence each other and that there is a long-term relationship of equilibrium.

With regard to newly launched low liquidity contracts, Fortenbery and Zapata (1997) examined the relationship between the futures and spot prices of cheddar cheese, diammonium phosphate and anhydrous ammonia. Their analysis was based on the relationship of cointegration between spot and future prices, and their findings revealed long-term relationships in diammonium phosphate and ammonium sulfate contracts. This evidence, allied to the findings of Mattos and Garcia (2004), suggests that even futures markets of low liquidity can utilize the price discovery mechanism efficiently. 


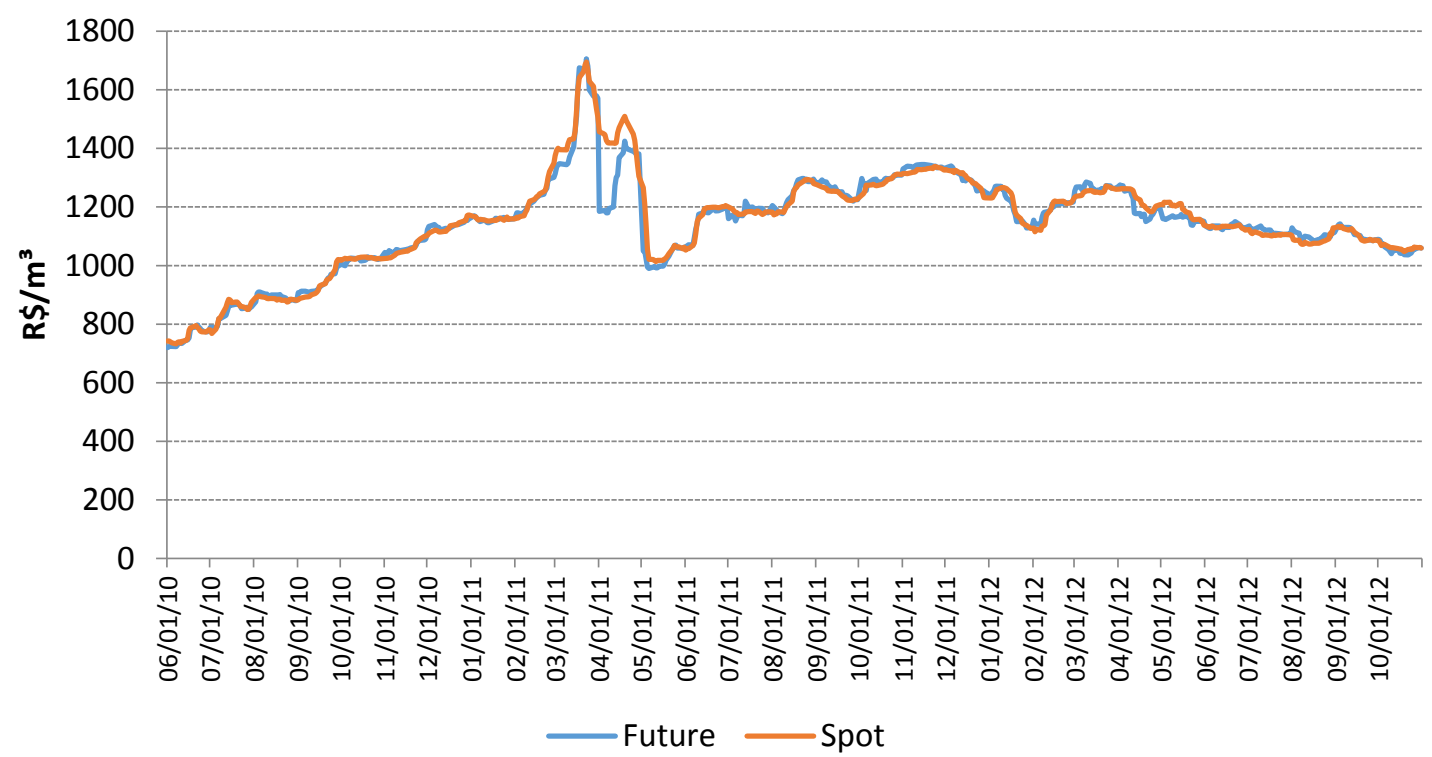

Figure 2. Evolution of ethanol futures and spot prices in Brazil.

He and Xie (2012) analyzed sugar spot and futures prices in China in order to verify the presence of market power or price discovery. They used daily spot price data from Guangxi Province, the country's largest sugar producer, and futures prices from the Zhengzhou Commodity Exchange between January 2006 and September 2009. Their methodology was based on Johansen's cointegration analysis with error correction and variance decomposition of spot and futures prices through Hasbrouck's information shares approach. They found that the sugar futures market is efficient in price discovery and information transmission. Spot and futures prices are cointegrated, the future price Granger causes the spot price, and spot prices are more informative than futures prices. Moreover, they found that (i) irrational speculation distorts the pricing mechanism; (ii) oligopolies and local government politics hinder the participation of agents in the sugar futures market; and (iii) the wholesale sugar market somehow substitutes the use of futures markets.

Specifically with regard to anhydrous ethanol futures contracts in Brazil, Alves et al. (2008) studied the efficiency of this market. The authors used the Johansen cointegration procedure with error correction, relating the weekly spot and future prices between July 2000 and May 2006. They observed that the levels of the series were not stationary, except when considered in their first difference, i.e., they were integrated of order one.

The efficient market hypothesis $(\mathrm{EMH})$ is a backbreaker for forecasters. It is associated with the idea of a "random walk," which is a term loosely used in the finance literature to characterize a price series where all subsequent price changes represent random departures from previous prices. The EMH maintains that market prices fully reflect all available information. Developed independently by Paul A. Samuelson and Eugene F. Fama in the 1960s, this idea has been applied extensively to theoretical models and empirical studies of financial securities prices, generating considerable controversy as well as fundamental insights into the price-discovery process. Timmermann and Granger (2004) considered the importance of the information set adopted in the test. It was found that although the variables presented cointegration, the hypothesis of weak market efficiency was rejected.

The next section explains the methods adopted in this work, starting with the analysis of cointegration and concluding with the methodology of price discovery proposed by Lien and Shrestha (2009), following Christofoletti et al. (2012). Lien and Shrestha's approach, as will be shown later, represents an advance on Hasbrouck's method, used by He and Xie (2012) to analyze the relationship between spot and futures sugar prices in China. 


\section{Methodology}

Engle and Granger (1987) define cointegration as follows: let $X_{t}$ be a row vector of dimension $N$. The components of $X_{t}$ have cointegration of order $(d, b)$ if: (i) all their components are $I(d)$; (ii) there is a row vector $\alpha \neq 0$ such that $Z_{t}=\alpha^{\prime} X_{t} \sim I(d-b), b>0$. The vector $\alpha$ is defined as the cointegration vector.

For the pth-order cointegrated VAR model, the error correction form is:

$$
\Delta Y_{t}=\Pi Y_{t-1}+\sum_{k=1}^{p-1} \Gamma_{k} \Delta Y_{t-k}+\mu_{t}
$$

The coefficients matrix $\Pi$ is the cointegrating matrix and it has long-run information. The number of eigenvalues of $\Pi$ that are statistically different from zero, i.e., the rank of $\Pi$, corresponds to the number of cointegrating vectors. Johansen establishes the statistics of the trace and maximum eigenvalue as follows:

$$
\begin{gathered}
\lambda_{\text {trace }}(r)=-T+\sum_{i=r+1}^{n} \ln \left(1-\hat{\lambda}_{i}\right) \\
\lambda_{\max }(r, r+1)=-T+\ln \left(1-\hat{\lambda}_{r+1}\right)
\end{gathered}
$$

where $\hat{\lambda}_{i}$ are estimated values of eigenvalues obtained from matrix $\Pi$, and $T$ is the number of observations. The null hypothesis is that there is a maximum of $r$ cointegrated vectors.

So, the following equations will be estimated by the Johansen procedure to verify the existence of short- and long-term relationships, according to Equations (4) and (5):

$$
\begin{aligned}
& \Delta F_{t}=\delta+\theta E C M_{t-1}+\sum_{k=1}^{q} \varphi_{k} \Delta F_{t-k}+\sum_{j=1}^{q} \psi_{j} \Delta S_{t-j}+\mu_{t} \\
& \Delta S_{t}=\xi+\gamma E C M_{t-1}+\sum_{k=1}^{q} \Phi_{k} \Delta F_{t-k}+\sum_{j=1}^{q} \omega_{j} \Delta S_{t-j}+\varepsilon_{t}
\end{aligned}
$$

where $\Delta F_{t}$ and $\Delta S_{t}$ are the first difference of future and spot prices, respectively, and $E C M_{t-1}$ is the error correction term, defined by $E C M_{t-1}=\ln \Delta S_{t}-\tau \ln \Delta F_{t}$, which reflects the speed of adjustment to restore long-term equilibrium.

Granger causality tests (Granger 1988) only the direct relationship between variables, i.e., the variables move in unison. The variance decomposition arising from the information share (herein after referred to as IS) proposed by Hasbrouck (1995) is a model based on the reactions of variables when subjected to shocks, which are divided into transitory and permanent shocks.

The permanent component is called a common factor or common efficient price, and this method assumes that volatility reflects new information and assigns higher price discovery to the market that contributes most to the efficiency variances in the common price.

Considering that there is no autocorrelation in innovations, Hasbrouck (1995) defines IS as follows:

$$
I S_{j}=\frac{\psi_{j}^{2} \Omega_{j j}}{\psi \Omega \psi^{T}}
$$

where $\Omega$ is the covariance matrix of prices and $\psi$ is the sum of the coefficients of the moving average prices. Therefore, the expression $\psi_{j}^{2} \Omega_{j j}$ represents the market's participation $j(j=1, \ldots, n)$ in the variance of the common factor, denoted by $\psi \Omega \psi^{T}$.

If the covariance-variance matrix is not diagonal, then the IS is defined as:

$$
I S_{j}=\frac{\left([\psi F]_{j}\right)^{2}}{\psi \Omega \psi^{T}}
$$


where $F$ is the Cholesky decomposition of $\Omega$ and its lower triangular matrix, and $[\psi F]_{j}$ is the $j$-nd element of row vector $\psi F$.

Since the IS of Hasbrouck (1995) uses the estimation of an error correction model that decomposes the effect of shocks, this implies that the IS can provide different estimates, depending on the ordering of the prices in the system. In this regard, the estimation of IS will also be performed in reverse order.

Lien and Shrestha (2009) overcome this limitation and propose a measure that offers uniqueness in price discovery, in other words, independent of the order of the price series, denoted by MIS (Matrix Information Share) according to Equation (8):

$$
M I S_{j}=\frac{\left(\left[\psi F^{*}\right]_{j}\right)^{2}}{\psi \Omega \psi^{T}}
$$

where $F^{*}=\left[G \Lambda^{-1 / 2} G^{T} V^{-1}\right]^{-1} . \Lambda$ is a diagonal matrix composed of the eigenvalues of the correlation matrix of innovations; $G$ is a matrix in which the columns are the corresponding eigenvectors, $V$ is a diagonal matrix and the elements on its main diagonal are standard deviations of the innovations.

It can be verified that $\Omega=F^{*}\left(F^{*}\right)^{T}$, and that this structure involves a full matrix rather than a lower triangular matrix, which implies uniqueness to measure price discovery.

\section{Data Description}

Two sets of hydrous ethanol prices were considered: spot and futures prices. Both prices were obtained from Brazilian Securities, Commodities and Futures Exchanges (BM\&F-BOVESPA) and are quoted in Brazilian currency ("Brazilian Reals") per 30 cubic meters.

The spot prices of ethanol refer to Paulínia, the largest fuel distributor hub in Brazil located in upstate São Paulo. São Paulo is the major producer province in Brazil, which was responsible for some $60 \%$ of the Brazilian ethanol supply in 2012.

Futures contracts on ethanol BM\&F-BOVESPA mature at the end of every month and are cash settled. The last trading day is the last business day of the maturity month. The trading unit of each futures contract is 30 cubic meters, and the underlying commodity is defined in accordance with the technical specifications of the National Petroleum Agency (ANP). Nearby futures contracts were considered and the series is rolled over to the next maturity on the last day of the contracts.

In May 2010, the BM\&F-BOVESPA relaunched ethanol futures contracts. This is the third attempt to establish an efficient alternative to managing the price risks of ethanol in Brazil. Therefore, the period of analysis focused between 1 June 2010 and 31 October 2012.

\section{Results}

We analyzed the stationarity of the series by means of ADF (Augmented Dickey-Fuller), ADF-GLS (Generalized Least Squares) and PP (Phillips-Perron) tests. In these tests, the null hypothesis is the existence of a unit root (non-stationarity). We applied these tests in both, without and with first-difference form, considering models with constant performance. The Schwarz's Bayesian Information Criterion (BIC) determines the maximum lag. Tables 1 and 2 show the descriptive statistics of the ethanol prices and the augmented Dickey-Fuller test (Dickey and Fuller 1979), respectively.

Table 1. Descriptive statistics of ethanol prices-units in Brazilian Reals $/ \mathrm{m}^{3}$.

\begin{tabular}{cccccccc}
\hline & Avg. & Median & Std. Dev. & Skewness & Kurtosis & Maximum & Minimum \\
\hline Spot & 1147.22 & 1156.75 & 164.41 & -0.09 & 3.83 & 1694.00 & 732.50 \\
Future & 1142.45 & 1154.00 & 159.62 & -0.15 & 4.10 & 1705.00 & 720.00 \\
\hline
\end{tabular}


Table 2. Stationarity tests.

\begin{tabular}{|c|c|c|c|c|c|}
\hline Prices & $\mathrm{ADF}$ & ADF-GLS & PP & $\tau_{\mu} H_{0}: \beta_{2}=0$ & $\tau_{\tau} H_{0}: \beta_{2}=0$ \\
\hline Spot & -0.06 & -0.81 & -2.16 & $-2.99 *$ & -2.80 \\
\hline Future & 0.04 & -0.82 & -2.80 & -2.83 & -2.58 \\
\hline$\Delta$ Spot & $-8.42 *$ & $-8.31^{*}$ & -10.74 * & $-8.42 *$ & $-8.48 *$ \\
\hline$\Delta$ Future & $-15.13^{*}$ & $-8.52 *$ & $-22.63 *$ & $-15.12 *$ & $-15.16^{*}$ \\
\hline
\end{tabular}

* significant at 5\% level. ADF: Augmented Dickey-Fuller test; ADF-GLS: Generalized Least Squares test; PP: Phillips-Perron test.

The cointegration estimation results are provided by Tables 3 and 4 . The statistics trace and $\chi_{\max }$ suggest that there is a cointegration relationship between the variables at the $5 \%$ level of significance. This result suggests that there is long-run relationship between the spot and futures prices of ethanol in Brazil.

Table 3. Cointegration tests: trace.

\begin{tabular}{ccccc}
\hline Trace & Stat & Critical Level (5\%) & Critical Level (1\%) & Results \\
\hline $\mathrm{H}_{0}: \mathrm{r}=0$ & 56.27 & 19.96 & 24.6 & Reject \\
$\mathrm{H}_{0}: \mathrm{r} \leq 1$ & 7.96 & 9.24 & 12.97 & Do not reject \\
\hline
\end{tabular}

Table 4. Cointegration tests: eigenvalue.

\begin{tabular}{ccccc}
\hline Xmax & Stat & Critical Level (5\%) & Critical Level (1\%) & Results \\
\hline $\mathrm{H}_{0}: \mathrm{r}=0$ & 48.3 & 15.67 & 20.20 & Reject \\
$\mathrm{H}_{0}: \mathrm{r} \leq 1$ & 7.96 & 9.24 & 12.97 & Do not reject \\
\hline
\end{tabular}

Observing the values of the coefficients of the Error correction model ECM in Table 5, only the coefficient on the futures market is significant, indicating that the dynamics of the futures price restores long-term equilibrium in case of deviation of the path. The estimated coefficients indicate that there is a relationship between the two prices, but only the futures price makes the adjustment after deviations from the equilibrium. This suggests that the spot market is the "dominant" market in this relationship. This result is consistent with the fact that the futures market has very low liquidity, hence futures prices are probably not representative of current market conditions and end up just following whatever happens in the spot market. Also, one observes that spot and future prices are significant in ethanol price determination in Brazil. However, due to the low liquidity of the futures contracts, it is possible that few agents in that market can obtain important information, in advance, about the mean spot price behavior. Thus, the future price tends to "follow" the spot market. Furthermore, the future price is defined before $(15: 25 \mathrm{~h})$ and the spot price at $(18: 00 \mathrm{~h})$. This can explain the fast reaction of the future prices when one can obtain new information about the market behavior.

Table 6 highlights the MIS decomposition between the spot and futures price. It is observed that the spot price is predominant in the ethanol price discovery process. Based on these results, there is evidence that the spot market is the main price discovery source of ethanol, in other words, the spot market is more informative than the futures market. 
Table 5. Vector error correction model VECM-Ethanol prices.

\begin{tabular}{lcc}
\hline \multicolumn{1}{c}{ Variables } & Spot & Future \\
\hline$E C M_{t-1}$ & -0.0015 & $0.1865^{* * *}$ \\
$\Delta S_{t-1}$ & $0.5767^{* * *}$ & $0.7427^{* * *}$ \\
$\Delta F_{t-1}$ & 0.0159 & 0.0084 \\
$\Delta S_{t-2}$ & $0.0971^{*}$ & 0.1549 \\
$\Delta F_{t-2}$. & $0.0408^{* *}$ & -0.0091 \\
$\Delta S_{t-3}$ & 0.0422 & 0.195 \\
$\Delta F_{t-3}$ & $0.0803^{* * *}$ & -0.0102 \\
$\Delta S_{t-4}$ & -0.0108 & $-0.4142^{* * *}$ \\
$\Delta F_{t-4}$ & -0.0253 & -0.0648 \\
$\Delta S_{t-5}$ & $-0.0745^{*}$ & $0.5256^{* * *}$ \\
$\Delta F_{t-5}$ & $-0.0479^{* *}$ & -0.0215 \\
constant & 0 & 0 \\
\hline \multicolumn{2}{c}{$* * * * * *$ significant at $1 \%, 5 \%$ and $10 \%}$.
\end{tabular}

Table 6. Matrix Information Share (MIS).

\begin{tabular}{cc}
\hline Market & MIS (\%) \\
\hline Spot & 96.66 \\
Future & 3.34 \\
\hline
\end{tabular}

The leadership of the spot markets in price formation has a close relationship with the market's relative concentration in that sector. The greatest companies located in São Paulo (the greatest Brazilian state ethanol producer) can use their high tankage capacity in order to obtain higher prices in the off season when only few great producers are able to supply ethanol.

More specifically, according to Zanão and Caixeta-Filho (2011), the four greatest economic groups in São Paulo state hold more than half of the ethanol storage capacity in the same state.

Also, one can observe a market's relative concentration in wholesale. A lot of unities of ethanol producers form the marketing groups. They combine, among other reasons, to increase the bargaining power in negotiations with ethanol distributors.

With respect to the 2006/2007 harvest, in accordance with Dolnikoff (2008), 51.48\% of the ethanol production in the center-south region of Brazil, which accounts for approximately $90 \%$ of the national ethanol supply, was commercialized by just four groups.

However, the greatest concentration level occurs in the distribution sector. In 2009, the five greatest companies in the sector held approximately $65 \%$ of the trade involving hydrous ethanol in Brazil. According to Sindicom (National Union of Fuel and Lubricant Distribution Companies), in 2013, the market share in the distribution of hydrated ethanol was $20.5 \%$ for BR Distribuidora (Rio de Janeiro, Brazil), 18.8\% for Raízen (São Paulo, Brazil) and 18.7\% for Ipiranga (Porto Alegre, Brazil), and only $2.7 \%$ for Alesat (Natal, Brazil), the fourth one, out of a total of 152 distributors. In short, there is evidence indicating that the increase of trade concentration in the ethanol market may be due to the leadership of the spot markets vis-a-vis futures markets, in the long-term prices discovery process.

\section{Conclusions}

The purpose of this work was to examine the relationship between ethanol spot and futures prices in Brazil, after BM\&F-BOVESPA's third attempt to introduce ethanol futures contracts in the aforementioned country. The futures market was found to have less pricing power than the spot market, with the latter accounting for almost the whole of the long-term price discovery process.

This fact can be explained first by the relative concentration of ethanol in the wholesale market, with only a few groups holding a significant share of the market, and by the oligopolistic behavior of the distributors. A second explanation for the importance of spot prices is the regulation of the ethanol 
market by the Brazilian Federal Government and by the Petrobrás price and sell politics. These factors are important because they affect the expectations of the agents and their strategic options for buying and selling ethanol.

In sum, in order to understand the price mechanism of ethanol in Brazil, one must examine the institutional questions regarding the regulation of the markets. Furthermore, we highlighted that the most important contribution of this text is to show and explain the dynamics of a regulated market and the importance of understanding the role of coordination and of institutional rules.

Author Contributions: All authors contributed equally to the paper.

Conflicts of Interest: The authors declare no conflict of interest.

\section{References}

Alves, Janaína da Silva, Gisléia Sandrini Duarte, and Ricardo Chaves Lima. 2008. Teste da eficiência do mercado futuro do álcool anidro no Brasil: Uma análise de co-integração. Revista Econômica do Nordeste 39: 173-84. (In Portuguese)

Bekiros, Stelios D., and Cees G.H. Diks. 2008. The relationship between crude oil spot and futures prices: Cointegration, linear and nonlinear causality. Energy Economics 30: 2673-85. [CrossRef]

Bentivoglio, Deborah, Adele Finco, and Mirian Rumenos Piedade Bacchi. 2016. Interdependencies between biofuel, fuel and food prices: The case of the Brazilian ethanol market. Energies 9: 464. [CrossRef]

Burnquist, Heloisa Lee, Mirian Rumenos Piedade Bacchi, and Marta Cristina Marjotta-Maistro. 2002. Análise da comercialização dos produtos do setor sucroalcooleiro brasileiro: Evolução, contexto institucional e desempenho. In Agroindústria canavieira no Brasil: evolução, desenvolvimento e desafios. São Paulo: Atlas. (In Portuguese)

Christofoletti, Maria Alice Móz, Rodolfo Margato da Silva, and Fabio Mattos. 2012. The increasing participation of China in the world soybean market and its impact on price linkages in futures markets. In Paper presented at Conference on Applied Commodity Price Analysis, Forecasting and Market Risk Management, St. Louis, MO, USA.

De Freitas Vian, Carlos Eduardo. 2003. Agroindústria Canavieira. Estratégia Competitiva e Modernização. Campinas: Átomo. (In Portuguese)

De Moraes, Márcia Azanha Ferraz Dias. 2000. A Desregulamentação do Setor Sucroalcooleiro do Brasil. Americana: Caminho Editorial. (In Portuguese)

Dickey, David A., and Wayne A. Fuller. 1979. Distribution of the Estimators for Autoregressive Time Series with a Unit Root. Journal of the American Statistical Association 74: 427-31. [CrossRef]

Dolnikoff, Fabio. 2008. Contratos de etanol carburante e racionalidade econômica da relação entre usinas e distribuidoras de combustíveis no Brasil. Master's Dissertation, Faculdade de Economia, Administração e Contabilidade, Universidade de São Paulo, São Paulo, Brasília. (In Portuguese)

Engle, Robert F., and Clive W.J. Granger. 1987. Cointegration and error correction representation, estimation and testing. Econometrica 55: 251-76. [CrossRef]

Fortenbery, T. Randall, and Hector O. Zapata. 1997. An evaluation of price linkages between futures and cash markets for cheddar cheese. Journal of Futures Markets 17: 279-301. [CrossRef]

Gordinho, Margarida Cintra. 2010. Do Álcool ao Etanol: Trajetória Única. São Paulo: Terceiro Nome. (In Portuguese)

Granger, Clive William John. 1988. Some Recent Developments in a Concept of Causality. Journal of Econometrics 39: 199-211. [CrossRef]

Granger, Clive William John, and Paul Newbold. 1986. Forecasting Economic Time Series. London: Academic Press, p. 211.

Hasbrouck, Joel. 1995. One security, many markets: Determining the contributions to price discovery. Journal of Finance 50: 1175-99. [CrossRef]

He, Ling-Yun, and Wen-Si Xie. 2012. Who has the final say? Market power versus price discovery in China's sugar spot and futures contracts. China Agricultural Economic Review 4: 379-90. [CrossRef]

Lien, Donald, and Keshab Shrestha. 2009. A New Information Share Measure. The Journal of Futures Markets 29: 377-95. [CrossRef] 
Mattos, Fabio, and Philip Garcia. 2004. Price discovery in thinly traded markets: Cash and futures relationships in Brazilian agricultural futures markets. Paper presented at the Conference on Applied Commodity Price Analysis, Forecasting and Market Risk Management, St. Louis, MO, USA.

Mattos, Fabio, and Philip Garcia. 2006. Price Discovery and Risk Transfer in Thinly Traded Markets: Evidence from Brazilian Agricultural Futures Markets. Review of Futures Markets 14: 471-83.

Mattos, Fabio, and Philip Garcia. 2011. Changes in Liquidity, Cash Market Activity, and Futures Market Performance: Evidence from Live Cattle Market in Brazil. In Paper presented at the NCCC-134 Conference on Applied Commodity Price Analysis, Forecasting and Market Risk Management, St. Louis, MO, USA.

Perobelli, Fabiana Salgueiro. 2005. As relações entre o preço à vista e futuro: Evidências para o mercado de boi gordo no Brasil. In Paper presented at the Congresso da Sociedade Brasileira de Economia e Sociologia Rural, Ribeirão Preto, São Paulo, Brasília. (In Portuguese)

Quintino, Derick David, and Sergio Adriani David. 2013. Quantitative analysis of feasibility of hydrous ethanol futures contracts in Brazil. Energy Economics 40: 927-35. [CrossRef]

Ramos, Pedro. 1983. Um estudo da Evolução e da Estrutura da Agroindústria Canavieira no Estado de São Paulo. Master's Dissertation, Getúlio Vargas Foundation, São Paulo, Brasil. (In Portuguese)

Serra, Teresa, David Zilberman, and José Gil. 2011. Price volatility in ethanol markets. European Review of Agricultural Economics 38: 259-80. [CrossRef]

Szmrecsányi, Tamás. 1979. O Planejamento da Agroindústria Canavieira No Brasil (1930-1975). São Paulo: Hucitec. (In Portuguese)

Timmermann, Allan, and Clive W.J. Granger. 2004. Efficient market hypothesis and forecasting. International Journal of Forecasting 20: 15-27. [CrossRef]

Zanão, Aline Gisele, and Jose Vicente Caixeta-Filho. 2011. Caracterização da infraestrutura de armazenagem de álcool no Brasil e análise da sua concentração na Região Centro-Sul. In Desafios e Perspectivas Para o Setor Sucroenergético do Brasil. Edited by Marta Cristina Marjotta-Maistro. São Carlos: EdUFSCAR, pp. 211-26. (In Portuguese)

(C) 2017 by the authors. Licensee MDPI, Basel, Switzerland. This article is an open access article distributed under the terms and conditions of the Creative Commons Attribution (CC BY) license (http:/ / creativecommons.org/licenses/by/4.0/). 